\title{
Distribution of arsenic and mercury in subtropical coastal beachrock, Gulf of Mannar, India
}

\author{
J Dajkumar Sahayam ${ }^{1, *}$, N ChandrasekaR ${ }^{1}$, S Krishna Kumar ${ }^{1}$ and \\ G Victor RAJAMANICKAM ${ }^{2}$ \\ ${ }^{1}$ Centre for GeoTechnology, Manonmaniam Sundaranar University, Tirunelveli, Tamil Nadu 627 012, India. \\ ${ }^{2}$ Centre for Advance Research in Indian System of Medicine, Sastra University, Thanjavur, \\ Tamil Nadu 613 402, India. \\ *e-mail: dajkumar_j@yahoo.com
}

An assessment of coastal pollution was made on the basis of trace element concentrations (arsenic As, mercury - $\mathrm{Hg}$ ) in the Gulf of Mannar. The beachrock samples were collected along the coastal tracts between Rameswaram and Kanyakumari. The samples were dried and digested to determine the $\mathrm{As}$ and $\mathrm{Hg}$ using atomic absorption spectrophotometer (AAS-air-acetylene and nitrous oxide method). The As and $\mathrm{Hg}$ accumulation status of the beachrock was assessed using geo-accumulation index values $\left(I_{\text {geo }}\right)$. The accumulation of $\mathrm{As}$ and $\mathrm{Hg}$ in the beachrock ranges from 2.75 to $20.72 \mu \mathrm{g} \mathrm{g}^{-1}$ and from 0.06 to $0.31 \mu \mathrm{g} \mathrm{g}^{-1}$, respectively. The As and $\mathrm{Hg}$ concentrations in the beachrocks are compared with crustal average values and average of other region sediments. The possible source of the contamination is from atmospheric deposition and anthropogenic activities.

\section{Introduction}

Technological and industrial developments along the coast have contributed more heavy metals into the coastal environment. In addition, the anthropogenically induced changes in the coastal environment such as land reclamation, dredging and aquaculture might induce the metal pollution (Antonio Cobelo-Garcia and Ricardo Prego 2003). The heavy metals in the environment have many sources:

- geological weathering of rocks

- industrial wastes and processing effluents

- leaching of solid waste dumps and garbage

- animal and human excreta (Forstner and Wittmann 1981).

Estuarine and coastal sediments usually act as sinks of river borne metal released by weathering and human activities in terrestrial environments (Salomons and Fornster 1984). The total concentrations of heavy metal pollution in the coastal sediments are not considered as potential hazards of the coastal zone. The potential availability of heavy metal in the coastal environment is dependent on the metal accumulation and the binding strength with sedimentary phases (Marins et al 1998).

The beachrock formed in the intertidal zone, would be used to interpret the coastal pollution. The beachrocks are characterized by a high content of carbonate minerals, feldspar with significant amount of shelly matter and quartz. Many researchers have studied the beachrocks and relative sea level variations in the west and east coasts of India (Wagle 1990; Loveson 1994; Banerjee 2000; Kumar et al 2001; Rao et al 2003; Sahayam 2005). However, no comprehensive study has been carried out in this coast to assess the As and $\mathrm{Hg}$ concentration in the beachrocks. The aim of the present study is to measure the concentration of arsenic (As) and mercury $(\mathrm{Hg})$ in subtropical beachrocks

Keywords. Beachrock; Gulf of Mannar; As; Hg; subtropical coast. 


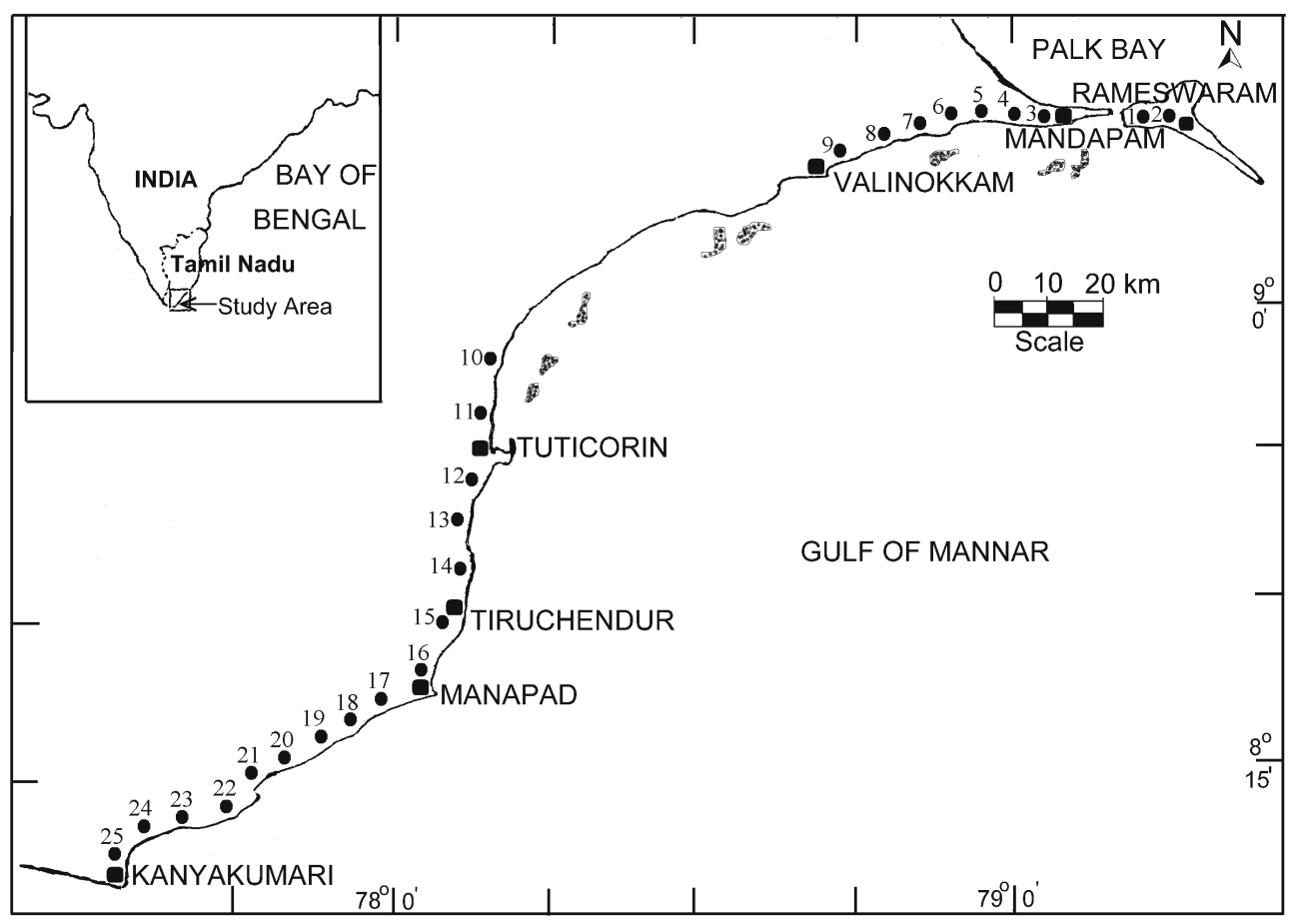

Figure 1. Study area and beachrock sample locations of the Gulf of Mannar, India.

collected from the Gulf of Mannar coastal region of India.

\section{Study area}

The Gulf of Mannar is located in the southeastern coast of India. It is a shallow embayment between Bay of Bengal and Indian Ocean. The Gulf of Mannar coastal zone receives rainfall from northeast monsoon. The river Thamirabarani is the only perennial river present in the study area. The ephemeral streams such as Vaippar, Gundar, Karaimanayar and Nambiyar have runoff during the monsoon periods. This study area enjoys subtropical climate condition. The Gulf of Mannar region consists of 21 coral islands between Rameswaram and Tuticorin. This marine region is one of the main marine bio-reserve declared by Government of India.

The beachrock is located along the coastal stretches of $360 \mathrm{~km}$ from Rameswaram to Kanyakumari in southeastern coast of Tamil Nadu (figure 1). The beachrocks are found along the coast as isolated patches and pockets with greater intervals between one and another formation. The area of investigation is a southern part of south Indian granulitic facies terrain, which includes part of Madurai Block (MB) and the Kerala Khondalite Belt (KKB) and it is mainly composed of charnockites and gneisses, which are interbedded with metasedimentary sequences. The MB and KKB are separated by Achankoil
Shear zone (AKSZ). A narrow strip of Cenozoic sedimentary formation covered along the coast about 10 to $12 \mathrm{~km}$, comprising Tertiary carbonates and Holocene sediments (figure 2). The southern part of the study area is dominated by riverine process when compared to the northern part of the study area. The terrace and majority of the beachrock occurring of the southeastern coast of Tamil Nadu were formed during the Pleistocene and Holocene to recent periods (Stoddart and Gopinathapillai 1972; Rajamanickam and Loveson 1990; Banerjee 2000; Sahayam 2005). In this study area, beachrocks are predominantly occurring in the intertidal regions. Moreover, northern part beachrocks are predominantly segregated by corals, shelly fragments and other marine organisms and the southern part beachrocks are probably derived from riverine sources (Hashimi and Nair 1976; Ray et al 1990). The dominancy of carbonates and the deficiency of silicates in the beachrock suggest fluviomarine-detrital origin of the beachrock formations (Sahayam 2005).

\section{Materials and methods}

The samples were collected from 25 locations along the intertidal zone, Gulf of Mannar with special consideration of facies criteria on lithology, sedimentary structures and textures, fossil content, stratigraphic relationships, geometric shapes of rocks and thickness of the strata. The rapid cementation of sediments, even within few years in the 


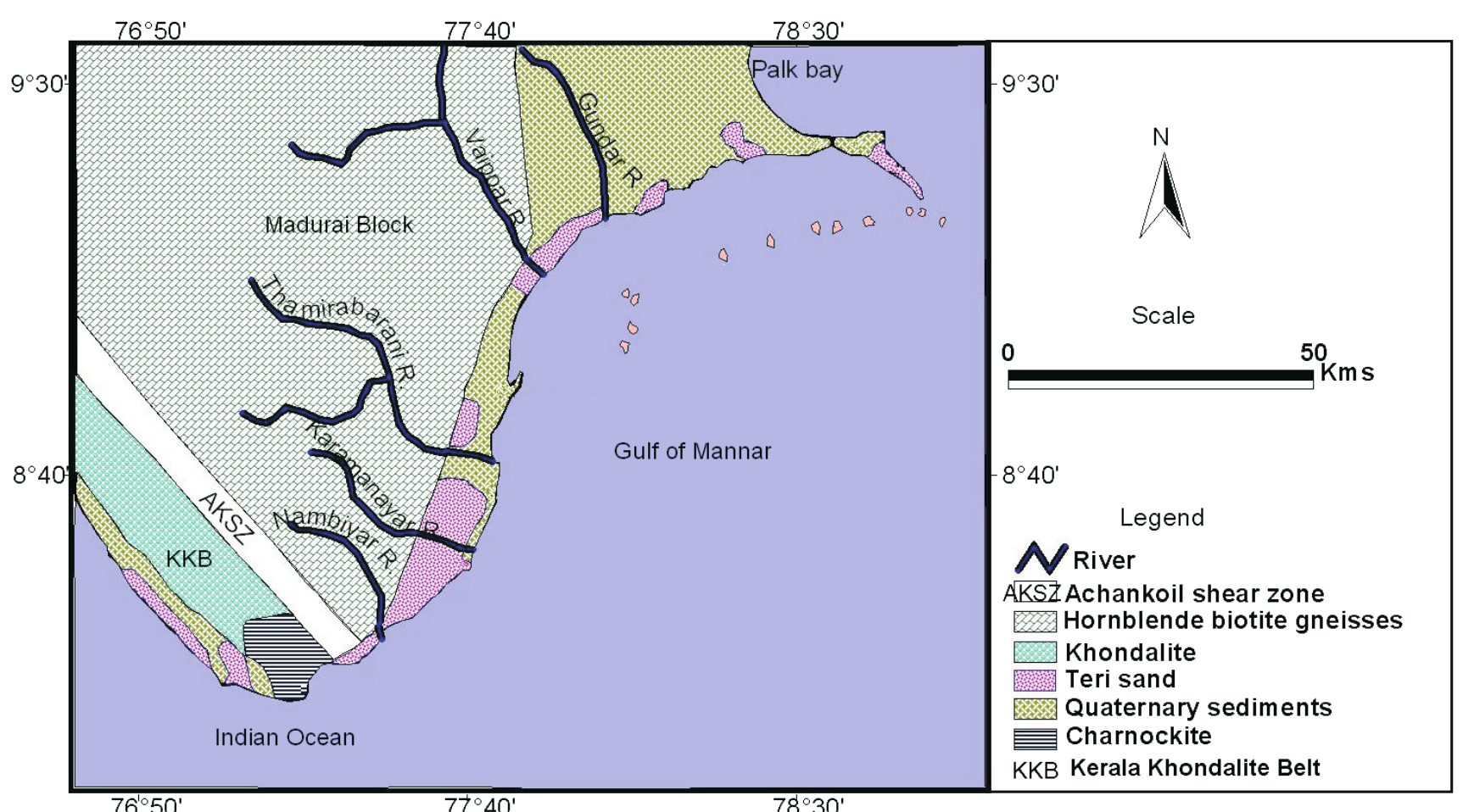

Figure 2. Geological map of the study area, Gulf of Mannar, India.

intertidal zone on tropical and subtropical climate beaches leads to the formation of beachrocks (Strasser et al 1989; Rey et al 2004). The mineralogy of the beachrock changed depending upon the beach sand mineral assemblages during the lithification of beachrocks. The samples were collected using stainless steel coated chisel to avoid contamination of the samples and make the subsamples for laboratory analysis. The beachrock subsamples were dried under sunlight for a day and transferred to the laboratory.

The samples were crushed using agate pestle and mortar before being adopted for laboratory analytical procedures. The samples were digested with triple acid combinations ( $\mathrm{HCL}, \mathrm{HNO}_{3}$ and $\mathrm{HF}$ ) as suggested by Loring and Rantala (1992). Powdered beachrock sample of $0.15 \mathrm{~g}$ was placed in a Teflon bomb, $1 \mathrm{ml}$ of aqua regia (AR grade $\mathrm{HNO}_{3}: \mathrm{HCl}$ in $1: 3 \mathrm{v} / \mathrm{v}$ ) was added and followed by $6 \mathrm{ml}$ of HF. The sealed bomb was allowed to digest under submerged boiling water bath (2 hours and 30 minutes). The flask was filled to a volume of $100 \mathrm{ml}$ with high purity distilled water. $\mathrm{CaCO}_{3}$ was analysed using titration method. Mercury concentrations were determined by $\mathrm{SnCl}_{2}$ reduction method (Goncalves 1993). As was analyzed by atomic absorption spectroscopy using nitrous oxide and acetylene gases and these values were calibrated by acidified standards (Model no-GBC Avanta 932). The laboratory results showed recovery efficiency ranges from $95 \%$ to $100 \%$ and coefficient of variation (CV) 6-9\% for studied trace elements. Detection limit of $\mathrm{As}$ and $\mathrm{Hg}$ ranges from $0.03 \mathrm{ppm}$ and $1 \mathrm{ppb}$.

\section{Results and discussions}

\subsection{Petrography of beachrocks}

The Gulf of Mannar beachrocks are heterogeneous mixtures of organic and inorganic matters and chiefly composed of quartz sand, heavy minerals, biogenic carbonate such as coral and shelly fragments derived from detritus inputs such as rivers, coastal erosion and other local available sources. The mean grain size of the beachrock ranges from $0.84 \phi$ to $3.03 \phi$. The concoction of medium sands with fine sediments reveals the active role of waves and currents in the redistribution of sediments. Sand domination in the few beachrock is observed along the study area with more than $75 \%$ of sand. The high concentration of calcareous sediments in the beachrock of the study area is suggested that the indication of low energy level with $40-60 \%$ calcareous sediments. The presence of heavy minerals in the beachrock may be due to the presence of heavy minerals with sediments in the intertidal zone during lithification. The increasing of fine grain sediments in the few locations is an indication of riverine inputs and low intensity of waves and currents during lithification process 
Table 1. Sample location numbers, co-ordinates, $\mathrm{CaCO}_{3}$ content, As and Hg distribution in beachrocks, Gulf of Mannar, Southeast coast of India.

\begin{tabular}{|c|c|c|c|c|c|c|c|c|}
\hline Sl. no & Latitude & Longitude & $\begin{array}{l}\text { Sediment } \\
\text { type }\end{array}$ & $\begin{array}{c}\mathrm{SiO}_{2} \\
(\%)\end{array}$ & $\begin{array}{c}\mathrm{Al}_{2} \mathrm{O}_{3} \\
(\%)\end{array}$ & $\begin{array}{c}\mathrm{CaCO}_{3} \\
(\%)\end{array}$ & $\begin{array}{c}\mathrm{As} \\
\left(\mu \mathrm{g} \mathrm{g}^{-1}\right)\end{array}$ & $\begin{array}{c}\mathrm{Hg} \\
\left(\mu \mathrm{g} \mathrm{g}^{-1}\right)\end{array}$ \\
\hline 1 & $09^{\circ} 17^{\prime} 26^{\prime \prime}$ & $79^{\circ} 19^{\prime} 21^{\prime \prime}$ & $\begin{array}{l}\text { Biogenic } \\
\text { Calcareous }\end{array}$ & 3.16 & 1.32 & 87.38 & 6.17 & 0.06 \\
\hline 2 & $09^{\circ} 17^{\prime} 26^{\prime \prime}$ & $79^{\circ} 19^{\prime} 21^{\prime \prime}$ & $\begin{array}{l}\text { Sandy } \\
\text { Calcareous }\end{array}$ & 3.23 & 0.84 & 92.46 & 5.17 & 0.1 \\
\hline 3 & $09^{\circ} 17^{\prime} 33^{\prime \prime}$ & $79^{\circ} 14^{\prime} 42^{\prime \prime}$ & Calcareous & 5.12 & 1.35 & 86.99 & 4.72 & 0.07 \\
\hline 4 & $09^{\circ} 17^{\prime} 33^{\prime \prime}$ & $79^{\circ} 14^{\prime} 42^{\prime \prime}$ & Calcareous & 3.32 & 1.45 & 88.37 & 5.46 & 0.11 \\
\hline 5 & $09^{\circ} 17^{\prime} 33^{\prime \prime}$ & $79^{\circ} 14^{\prime} 42^{\prime \prime}$ & Calcareous & 3.07 & 1.18 & 91.77 & 6.34 & 0.12 \\
\hline 6 & $09^{\circ} 17^{\prime} 33^{\prime \prime}$ & $79^{\circ} 14^{\prime} 42^{\prime \prime}$ & Calcareous & 1.84 & 0.52 & 89.44 & 2.75 & 0.11 \\
\hline 7 & $09^{\circ} 17^{\prime} 19^{\prime \prime}$ & $79^{\circ} 13^{\prime} 07^{\prime \prime}$ & $\begin{array}{l}\text { Sandy } \\
\text { Calcareous }\end{array}$ & 1.16 & 0.52 & 90.03 & 15.24 & 0.2 \\
\hline 8 & $09^{\circ} 16^{\prime} 23^{\prime \prime}$ & $79^{\circ} 08^{\prime} 25^{\prime \prime}$ & Sandy & 3.16 & 1.12 & 86.26 & 14.81 & 0.16 \\
\hline 9 & $09^{\circ} 15^{\prime} 52^{\prime \prime}$ & $79^{\circ} 08^{\prime} 25^{\prime \prime}$ & Sandy & 1.94 & 0.36 & 89.15 & 13.13 & 0.15 \\
\hline 10 & $08^{\circ} 29^{\prime} 40^{\prime \prime}$ & $78^{\circ} 08^{\prime} 01^{\prime \prime}$ & Sandy & 3.64 & 1.35 & 88.23 & 14.73 & 0.29 \\
\hline 11 & $08^{\circ} 29^{\prime} 40^{\prime \prime}$ & $78^{\circ} 08^{\prime} 01^{\prime \prime}$ & Sandy & 2.33 & 1.09 & 88.42 & 17.67 & 0.23 \\
\hline 12 & $08^{\circ} 22^{\prime} 07^{\prime \prime}$ & $78^{\circ} 03^{\prime} 59^{\prime \prime}$ & Sandy & 3.16 & 0.91 & 90.27 & 19.33 & 0.22 \\
\hline 13 & $08^{\circ} 22^{\prime} 07^{\prime \prime}$ & $78^{\circ} 03^{\prime} 59^{\prime \prime}$ & Sandy & 4.17 & 1.59 & 90.49 & 17.33 & 0.18 \\
\hline 14 & $08^{\circ} 22^{\prime} 07^{\prime \prime}$ & $78^{\circ} 03^{\prime} 59^{\prime \prime}$ & Sandy & 4.01 & 1.09 & 90.14 & 15.32 & 0.31 \\
\hline 15 & $08^{\circ} 22^{\prime} 07^{\prime \prime}$ & $78^{\circ} 03^{\prime} 59^{\prime \prime}$ & Sandy & 3.99 & 0.87 & 91.49 & 16.38 & 0.21 \\
\hline 16 & $08^{\circ} 11^{\prime} 08^{\prime \prime}$ & $77^{\circ} 48^{\prime} 10^{\prime \prime}$ & $\begin{array}{l}\text { Biogenic } \\
\text { Calcareous }\end{array}$ & 3.99 & 0.96 & 91.93 & 17.31 & 0.25 \\
\hline 17 & $08^{\circ} 10^{\prime} 21^{\prime \prime}$ & $77^{\circ} 45^{\prime} 42^{\prime \prime}$ & Sandy & 2.01 & 1.02 & 89.73 & 11.42 & 0.15 \\
\hline 18 & $08^{\circ} 10^{\prime} 21^{\prime \prime}$ & $77^{\circ} 45^{\prime} 42^{\prime \prime}$ & Sandy & 3.16 & 1.62 & 90.52 & 9.02 & 0.17 \\
\hline 19 & $08^{\circ} 59^{\prime} 50^{\prime \prime}$ & $78^{\circ} 14^{\prime} 34^{\prime \prime}$ & Sandy & 4.27 & 1.01 & 88.07 & 13.41 & 0.15 \\
\hline 20 & $08^{\circ} 25^{\prime} 17^{\prime \prime}$ & $78^{\circ} 04^{\prime} 01^{\prime \prime}$ & Sandy & 2.96 & 1.45 & 90.33 & 18.98 & 0.27 \\
\hline 21 & $08^{\circ} 22^{\prime} 46^{\prime \prime}$ & $78^{\circ} 03^{\prime} 09^{\prime \prime}$ & Calcareous & 2.67 & 1.27 & 90.95 & 20.72 & 0.19 \\
\hline 22 & $08^{\circ} 10^{\prime} 55^{\prime \prime}$ & $77^{\circ} 44^{\prime} 06^{\prime \prime}$ & Sandy & 3.17 & 1.65 & 91.52 & 7.62 & 0.16 \\
\hline 23 & $08^{\circ} 21^{\prime} 22^{\prime \prime}$ & $78^{\circ} 03^{\prime} 59^{\prime \prime}$ & Silica rich & 49.92 & 18.06 & 25.02 & 8.07 & 0.12 \\
\hline 24 & $09^{\circ} 09^{\prime} 29^{\prime \prime}$ & $78^{\circ} 39^{\prime} 26^{\prime \prime}$ & Silica rich & 49.57 & 17.68 & 24.75 & 15.08 & 0.23 \\
\hline 25 & $08^{\circ} 57^{\prime} 56^{\prime \prime}$ & $78^{\circ} 12^{\prime} 51^{\prime \prime}$ & Silica rich & 57.22 & 15.95 & 19.73 & 16.6 & 0.16 \\
\hline Minimum & & & & 1.16 & 0.36 & 19.73 & 2.75 & 0.06 \\
\hline Maximum & & & & 57.22 & 18.06 & 92.46 & 20.72 & 0.31 \\
\hline Mean & & & & 9.04 & 3.08 & 79.35 & 12.51 & 0.17 \\
\hline $\mathrm{EF}$ & & & & - & - & - & 192.09 & 57.13 \\
\hline Mean $I_{\text {geo }}$ & & & & - & - & - & 4.26 & 0.0027 \\
\hline
\end{tabular}

$I_{\text {geo }}$ - Geo-accumulation index; EF - Enrichment factor.

(Thomson-Becker and Luoma 1985). The high $\mathrm{CaCO}_{3}$ in the study area indicates that the carbonate materials were derived from shelly fragments and adjacent landmass.

\subsection{Geochemistry}

As and $\mathrm{Hg}$ concentrations were analyzed for 25 beachrocks to understand the contamination level of the study area. The concentrations of $\mathrm{SiO}_{2}$, $\mathrm{Al}_{2} \mathrm{O}_{3}, \mathrm{CaCO}_{3}, \mathrm{As}$ and $\mathrm{Hg}$ are tabulated in table 1 . The clay materials, organic matters, iron and manganese oxides are one of the major sinks for metal contaminants (Alexander et al 1993; Hatje et al 2001). The association of As and $\mathrm{Hg}$ in the carbonate sediments reveals that they are likely to act as a carrier phase of these metals. The concentration of $\mathrm{SiO}_{2}$ ranges from 1.16 to 57.22, with an average concentration of $9.04 \%$ (St. 7 and 25). The high concentration of $\mathrm{SiO}_{2}$ in the beachrock is due to free quartz and sand rich sediments. The concentration of $\mathrm{Al}_{2} \mathrm{O}_{3}$ ranges from 0.36 to $18.06 \%$, with an average concentration of $3.08 \%$ (St. 9 and 23). The high percentage of $\mathrm{Al}_{2} \mathrm{O}_{3}$ concentration in the beachrocks is due to strong diurnal winds and seasonal inflow of rivers. The concentration of $\mathrm{CaCO}_{3}$ ranges from 19.73 to $92.46 \%$, with an average concentration of $79.35 \%$ (St. 25 and 2). The low concentration of $\mathrm{CaCO}_{3}$ in few stations is due to high wave energy condition/less availability of calcareous sediments.

The concentration of As ranges from 2.75 to $20.72 \mu \mathrm{g} \mathrm{g}^{-1}$, with an average concentration $12.51 \mu \mathrm{g} \mathrm{g}^{-1}$ and average crustal background 


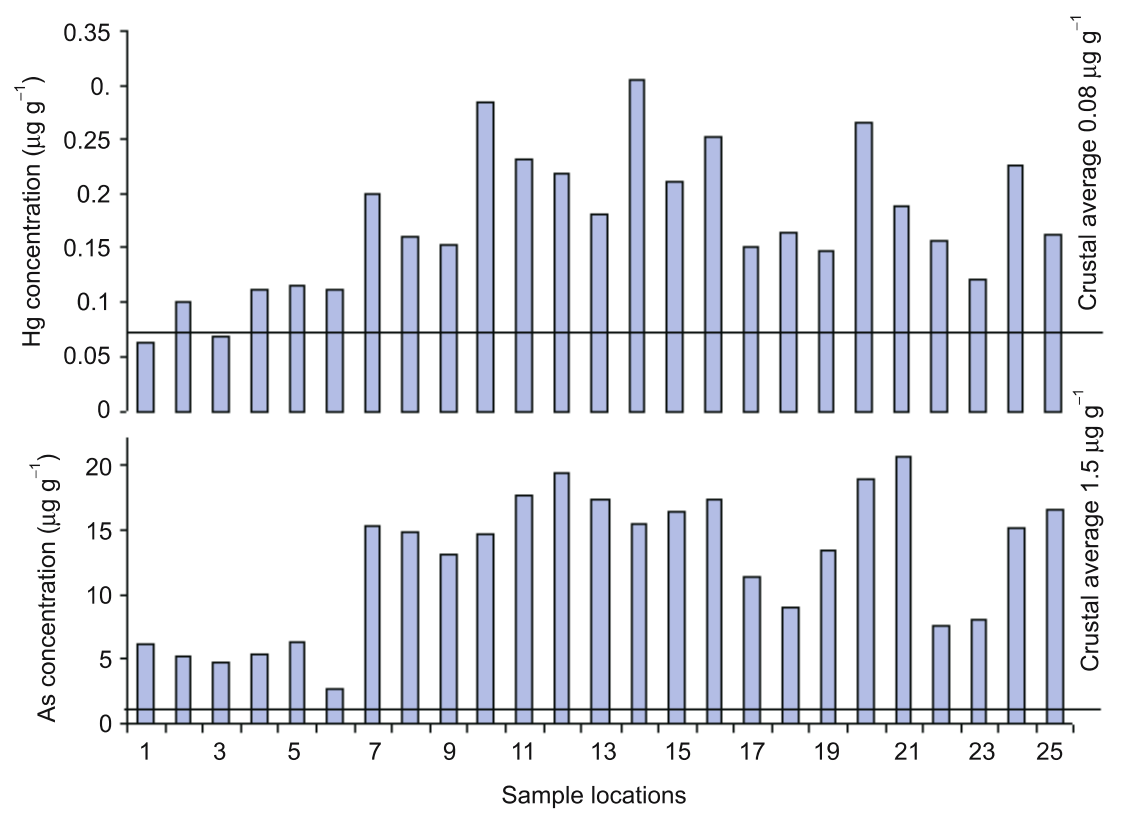

Figure 3. Comparison of As and $\mathrm{Hg}$ concentrations $\left(\mu \mathrm{g} \mathrm{g}^{-1}\right)$ in beachrocks, Gulf of Mannar with mean crustal average concentration of these elements.

values $1.5 \mu \mathrm{g} \mathrm{g}^{-1}$, respectively. The highest and lowest concentration levels of As were recorded at stations 22 and 7 . The high concentration of As in the southern part beachrock suggested that the beachrocks had suffered under the anthropogenic processes. The As and $\mathrm{Hg}$ concentration at stations 1-6 were lower than the ranges observed in the beachrocks of other stations.

The concentration of $\mathrm{Hg}$ ranged from 0.06 to $0.31 \mu \mathrm{g} \mathrm{g}^{-1}$ with an average concentration of $0.1743 \mu \mathrm{g} \mathrm{g}^{-1}$. The average crustal background value is $0.08 \mu \mathrm{g} \mathrm{g}^{-1}$. The higher and lower levels of $\mathrm{Hg}$ were noticed at stations 1 and 15 . The high concentration of $\mathrm{As}$ and $\mathrm{Hg}$ in the beachrocks is due to the confluence of industrial and domestic wastes through the river in the marine environment; it is well supported by a high concentration of $\mathrm{As}$ and $\mathrm{Hg}$ in the river vicinity beachrocks. The concentration of As and $\mathrm{Hg}$ in the northern part of the study area without significant river inlet makes one to understand that the prevalence of oxidizing environmental condition and the drifting of long shore currents from south to north. The sediment movement pattern in this study area also acknowledged northward movement of sediments (Cherian 2003). According to Clark (1994), the possible source of $\mathrm{Hg}$ in the beachrock is from atmospheric deposition (coal combustion and water incineration) and industrial discharge. The toxicities of $\mathrm{Hg}$ cause serious toxic consequences in marine species. The $\mathrm{As}$ and $\mathrm{Hg}$ concentrations are compared with crustal metal average values (figure 4). The trace element concentrations are comparatively higher in majority of the beachrocks than the crustal average values make one understand that these element concentrations in the beachrocks may be supplied from the anthropogenic activity. Comparison of the trace element concentrations in the sediments of various coastal regions suggested that the increase of As and $\mathrm{Hg}$ concentrations in the beachrock is derived from anthropogenic sources (table 3 ).

\subsection{Enrichment factor (EF) and geo-accumulation index $\left(I_{\text {geo }}\right)$}

As and $\mathrm{Hg}$ pollution was determined in this study using the element enrichment factor $(\mathrm{EF})$ and the index of geo-accumulation $\left(I_{\text {geo }}\right)$ values. Table 1 represents the mean values of calculated EF for the studied trace elements with respect to crustal average (Taylor 1964). Enrichment factor (EF) was calculated for each metals by dividing normalizing metal $(\mathrm{Al})$ by the background concentration ratio of the sediments and dividing of normalizing metal $(\mathrm{Al})$ by the background ratio of the crust. The Al is most successfully used as a normalizer, compensates for variations in grain size and composition because it represents the quality of alumino silicate, which is most important carrier phase for adsorbed metals in near shore sediments (Jonathan et al 2004). The mean EF level of arsenic and mercury for analyzed samples is 192 and 57 (table 1). According to Salomons and Fornster (1984), the $\mathrm{EF}$ level of $\mathrm{As}$ and $\mathrm{Hg}$ is elevated above 10 in the beachrock as a result of anthropogenic influences.

$$
\mathrm{EF}=(\text { metal } / \mathrm{Al})_{\text {sediments }} /(\operatorname{metal} / \mathrm{Al})_{\text {crust }} .
$$


Table 2. Comparison of $\mathrm{As}$ and $\mathrm{Hg}$ in the sediments with various regions around the world.

\begin{tabular}{llcl}
\hline Area & $\begin{array}{c}\text { As } \\
\text { concentration } \\
\left(\mu \mathrm{g} \mathrm{g}^{-1}\right)\end{array}$ & $\begin{array}{c}\mathrm{Hg} \\
\text { concentration } \\
\left(\mu \mathrm{g} \mathrm{g}^{-1}\right)\end{array}$ & \multicolumn{1}{c}{ References } \\
\hline In this study & 12.51 & 0.174 & - \\
Mean crust & 1.5 & 0.08 & Taylor (1964) \\
Mean sediments & 7.7 & $\mathrm{NA}$ & Salomons and Fornster (1984) \\
St. Anna Trough sediments, & $5.4-710$ & $94-3915$ & Siegel et al (2000) \\
Kara sea, Artic Ocean & 5.1 & 0.05 & Schiff and Weisberg (1999) \\
Southern California Bight & & & \\
\hline
\end{tabular}

Geo-accumulation index $\left(I_{\text {geo }}\right)$ allows finding out the contamination level of the investigated sediment. The index values of the $I_{\text {geo }}$ for the metal were calculated using Muller's expression (1979). Concentration of geochemical background values are multiplied each time by 1.5 in order to allow the metal content fluctuation of the samples in the environment.

$$
I_{\text {geo }}=\log _{2}\left[C_{n} /\left(1.5 \times B_{n}\right)\right]
$$

where $C_{n}$ is the concentration of metal in sediment samples and $B_{n}$ is the average concentration of the metal in earth crust. The calculated mean $I_{\text {geo }}$ values are presented in table 1 . The $I_{\text {geo }}$ values of the heavy metals pollution based on Muller's expression scale values are 0 - none, 1 - none to medium, 2 - moderate, 3 - moderately strong, 4 - strongly polluted, 5 - strong to very strong, and 6 - very strong. The $I_{\text {geo }}$ value of the analysed beachrock shows that the samples are strongly polluted by anthropogenic induced factors.

\section{Conclusion}

The As and $\mathrm{Hg}$ concentration in the beachrocks are lower in northern part of the study area when compared to southern part. This is due to the industrial pollutants and sewage confluence with river in the southern part of the study area. Moreover, the northward movement of sediments and currents are the pathways for the As and $\mathrm{Hg}$ concentration in the northern part. The concentration of As and $\mathrm{Hg}$ in the beachrock suggested that the elements migrated and accumulated along the Gulf of Mannar coast before the lithification of beach sediments. The comparison of crustal average and other coastal regions trace element concentration in the sediments indicate that they have contributed from anthropogenic sources. In addition, the calculated $I_{\text {geo }}$ values reveal that the beachrocks are strongly polluted by the anthropogenic activities. The pretreatment process on sewage and industrial effluents before draining in to adjoining rivers, channels and regular monitoring of coastal zones are given solution to address the coastal zone pollution problems.

\section{Acknowledgements}

The authors are highly thankful to Prof. M P Jonathan, Centro Interdisciplinario de Investigaciones y Estudios sobre Medio Ambiente y Desarrollo (CIIEMAD) Instituto Politécnico Nacional (IPN) for his critical suggestions and discussions during the course of this work. The author JDS personally acknowledges the Association of Geoscientist for International Development, Sao Paulo for extending the financial assistance to carryout the field work.

\section{References}

Alexander C R, Smith R G, Calder F D, Schropp S J and Windom H L 1993 The historical records of heavy metal enrichments in two Florida estuaries; Estuaries 16 627-637.

Antonio Cobelo-Garcia and Ricardo Prego 2003 Heavy metal sedimentary records in Galician Ria (NW Spain): Background values and recent contamination; Marine Pollution Bulletin 46 1253-1262.

Banerjee P K 2000 Holocene and Late Pleistocene relative sea level fluctuations along the east coast of India; Marine Geology 167 243-260.

Cherian A 2003 Sedimentological studies between Valinokkam and Tuticorin. Unpubl. Ph.D Thesis, Tamil University, $190 \mathrm{p}$

Clark R B 1994 Marine pollution (Oxford: Clarendon Press) 3rd edn., $172 \mathrm{p}$.

Forstner U and Wittmann G T W 1981 Metal pollution in the aquatic environment (Berlin: Springer) $486 \mathrm{p}$.

Goncalves G O 1993 Instrucao Tecnica, IT 003, Biblioteca CETEM, Rio de Janeiro, $6 \mathrm{p}$

Hashimi N H and Nair R R 1976 Carbonate components in the coarse fraction of western continental shelf (northern part) of India; J. Marine Sci. 5 51-57.

Hatje V, Birch G F and Hill D M 2001 Spacial and temporal variability of particulate trace metal in port Jackson Estuary, Australia; Estuar. Coast Shelf Sci. 53 63-67.

Jonathan M P, Rammohan V and Srinivasalu S 2004 Geochemical variations of major and trace elements in recent sediments, off the Gulf of Mannar, the southeast coast of India 45 466-480. 
Kumar B, Rajamanickam G V and Gujar A R 2001 Isotopic studies of beachrock carbonates from Konkan, Central West coast of India; In: Proc. Int. Quat. Sem. of INQUA shoreline (eds) Rajamanickam G V and Tooley M J, 140-147 pp.

Loring D H and Rantala R T T 1992 Manual for geochemical analyses of marine sediments and suspended particulate matter; Earth Sci. Rev. 32 235-283.

Loveson V J 1994 Geological and geomorphological investigations related to sea level variation and heavy mineral accumulation along the southern Tamil Nadu beaches, India, Unpublished Ph.D. Thesis, Madurai Kamaraj University, Madurai, $223 \mathrm{p}$.

Marins R V, Lacerda H, Paraquetti H M, De Paiva E C and Villas Boas R C 1998 Geochemistry of mercury in sediments of a sub-tropical coastal lagoon, Sepetiba Bay, Southern Brazil; Bull. Environ. Contam. Toxicol. 61 57-64.

Muller G 1979 Schwermetalle in den sediments des RheinsVeranderungen seitt 1971, Umaschan. 79 778-783.

Rajamanickam G V and Loveson V J 1990 Results of radiocarbon dating from some beach terraces around Rameswaram Island, Tamil Nadu; In: Sea Level Variation and its Impact on Coastal Environment (ed.) Rajamanickam G V, Tamil University, Thanjavur, 389-395 pp.

Rao V P, Rajagopalan G, Vora K H and Almeida F 2003 Late Quaternary sea level and environmental changes from relic carbonate deposits of the western margin of India; Proc. Indian Acad. Sci. (Earth Planet. Sci.) 112 $1-26$.

Ray S B, Rajagopalan G and Somayajulu B L K 1990 Radiometric studies of sediments cores from Gulf of Mannar; Indian J. Mar. Sci. 19 9-12.
Rey D, Rubio B, Bernabeu A M and Vilas F 2004 Formation, exposure and evolution of a high-latitude beachrocks in the intertidal zone of the Corrubedo complex (Rio de Arousa, Galicia, Nw Spain); Sedim. Geol. 169 93-105.

Sahayam J D 2005 Genesis of beachrock formation along the southeastern coast of Tamil Nadu and its significance to sea level variations; Unpublished Ph.D Thesis, Tamil University; 219 p.

Salomons W and Fornster U 1984 Metals in the Hydrocycle (New York: Springer Verlag) 349 p.

Schiff K C and Weisberg S B 1999 Iron as a reference elements for determining trace metal enrichment in Southern California coastal shelf sediments; Marine Env. Res. 48 161-176.

Siegel F R, Kravitz J H and Galasso J J 2000 Arsenic and mercury contamination in 31 cores taken in 1965, St. Anna Trough, Kara Sea, Arctic Ocean; Env. Geol. 40(4-5) 528-542.

Stoddart D R and Gopinathapillai C S 1972 Raised reefs of Ramanathapuram, South India; Trans. Inst. British. Geog. 56 111-125.

Strasser A, Davaud E and Jedoui Y 1989 Carbonate cements on Holocene beachrocks: Example from Bahiret el Biban, southern Tunisia; Sedim. Geol. 62 89-100.

Thomson-Becker E A and Luoma S N 1985 Temporal fluctuations in grain size, organic materials and iron concentrations in intertidal surface sediments of San Francisco Bay; Hydrobiologia 129 91-107.

Taylor S R 1964 Abundance of chemical elements in the continental crust: A new table; Geochem. Acta. 28 $1273-1285$.

Wagle B G 1990 Beachrocks of Goa coast; Geomarine Lett. $110111-115$ 